\section{ECONOMICS}

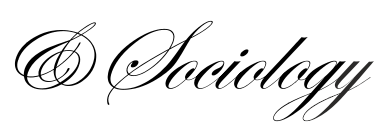

Kozhakhmetova, A., Zhidebekkyzy, A., Turginbayeva, A., \& Akhmetova, Z. (2019). Modelling of project success factors: A cross-cultural comparison. Economics and Sociology, 12(2), 219-234.doi:10.14254/2071-789X.2019/12-2/13

\title{
MODELLING OF PROJECT SUCCESS FACTORS: A CROSS-CULTURAL COMPARISON
}

\author{
Assel Kozhakhmetova, \\ Al-Farabi Kazakh National \\ University \\ Almaty, Kazakhstan, \\ E-mail: aselekdream@gmail.com
}

\author{
Aknur Zhidebekkyzy, \\ Al-Farabi Kazakh National \\ University, \\ Almaty, Kazakbstan, \\ E-mail:aknur.zh@gmail.com
}

\author{
Ardak Turginbayeva \\ Al-Farabi Kazakeh National \\ University, \\ Almaty, Kazakhstan, \\ E-mail:turginan@gmail.com
}

\section{Zauresh Akhmetova, Al-Farabi Kazakh National \\ University, \\ Almaty, Kazakhstan, \\ E-mail:raurebolat@mail.ru}

Received: December, 2018

1st Revision: March, 2019

Accepted: May, 2019

DOI: $10.14254 / 2071-$

789X.2019/12-2/13

JEL Classification:O22, M20, L69

\begin{abstract}
Project managers often run similar projects in a different way under the influence of particular factors. It is important to discover these factors, which may affect projects` success. The objectives of this study are to examine cultural differences in project running styles of three Asian countries with different level of economic development - Israel, Japan and Kazakhstan, and identify how their styles affect project success. The authors use PMPQ (Project Management Planning Quality) model for comparing the performance of project planning processes, organisational support level and the level of project success. The study investigates 681 private projects from different fields like engineering, software, communication and service. The results determine typically strong and weak areas of the chosen countries in performing planning quality, different level of project success due to national cultural differences. Japanese managers pay significant attention to time and cost scheduling and have better results than Israeli and Kazakh managers. Kazakh managers show the worst result in cost overrun $(25.96 \%)$ and low result in schedule overrun (32.9\%). The study reveals common and specific knowledge areas for each countries 'projects and helps measure their effect on project success.
\end{abstract}

Keywords: project management, national culture, PMPQ model, project planning, project success, Japan, Israel, Kazakhstan.

\section{Introduction}

Projects that contribute to social modernization and economic development of the country begin to acquire foreground importance in today's world (Bilovodska et al., 2017). Thus, project management practices are becoming increasingly important in doing business. They significantly differ between countries, and project managers often lead similar projects in a completely different way (Zwikael et al., 2005). Furthermore, over the past 40 years, a 
big amount of research has shown that managers in different countries make different strategic decisions and prefer different types of organizational structures (Shane, 1994). They do this under the influence of national cultural difference, which affects managers behaviour. It is important to explore these differences when projects often comprise of people and organizations from different national cultures such as multicultural teams, foreign managers, and international partners (Ress-Caldwell \& Pinnington, 2012). Because literature indicates that national culture affects project success and failure (Chevrier, 2003; Dafoulas \& Macaulay, 2001; Staples \& Zhao, 2006; Muriithi \& Crawford, 2003; Orr a\&nd Scott, 2008), the impact of national culture on project management processes attracts a lot of attention. For example, many scholars investigated cultural impacts on decision-making (Muller et al., 2013; Garbarino, 1967; Kun, 2009); communications (Ochieng \& Price, 2010); performance (Milosevic, 2002; Eriksson et al. , 2002; Yerznkyan et al., 2017); project team (Han et al., 2016; Jetu \& Riedl, 2013; Marrewijk, 2010; Ochieng \& Price, 2009; Remenova et al., 2018); leadership (Grisham et al., 2008; Yasin et al., 1997; Raisiene et al., 2018) while less attention is being paid to cultural impacts on planning quality and project success (Zwikael et al., 2005; Ress-Caldwell \& Pinnington, 2012).

Planning is a very important phase for the project because planning processes represent about $51 \%$ of all processes which should be performed by project managers. Also, planning is often identified in literature as a critical factor for project success (Zwikael \& Sadeh, 2007; Glenn, 2008; Serrador, 2013; Pinto \& Slevin, 1988). Literature reveals researches focused on cultural differences between Australia, India, New Zealand, British and Arab countries in project planning performance. But no studies have explored differences between an emerging economy of Kazakhstan and another country.

To better understand cultural differences in perception of project management tools and techniques our research investigates project planning processes, organizational support processes and success dimensions of Kazakhstani projects and compares the results with the findings on Israeli and Japanese projects, previously published by Zwikael et al. (2005).

The objectives of this study are to examine cultural differences in project running styles of Israel, Japan and Kazakhstan and to identify how their styles affect project success. Moreover, the authors compare the performance of project planning processes, organisational support level and the level of project success among these three countries. The study consists 6 sections. The first section describes the problem and the relevance of research. Section 2 provides literature background from previous researches in the chosen field. Section 3 describes the hypotheses offered on the basis of literature review. Section 4 explains the research methodology: the structure of the model and the data collection procedures. Section 5 presents the research results and their discussion. Finally, Section 6 concludes the paper.

\section{Literature review}

\subsection{Project planning}

The Project Management Body of Knowledge (PMBOK) identifies planning as of major importance to a project because it helps to select the best of the alternative courses of action to attain the objectives that the project was undertaken to address (PMI, 2008). It's important to study cultural differences in the planning phase, because project planning identified as one of the crucial factors which affect to project success or failure (Zwikael \& Sadeh, 2007; Milosevic, 2002). Many scholars reveal planning contribution to project success. For example, Pinto and Slevin (1988) claim that planning is considered in project management as one of the major contributors to project success. Furthermore, Glenn (2008) argued that project planning is one of the five common factors that can determine the success 
of an enterprise resource planning implementation. Findings from Dvir et al.'s (2002) study supported previous research results which found a significant positive relationship between the amount of efforts invested in the project planning process on one hand, and project success on the other. Ngai et al. conducted a literature review on Critical Success Factors (farther CSF) in the implementation of enterprise resource planning across 10 different regions. When considering project management, they state that a clear and defined project plan including goals, objectives, strategy, scope, schedule, and so forth was frequently cited in CSFs for in almost all of the regions and countries examined in their study (Ngai et al. 2008). All these studies show significance of planning, but don`t explore planning phase in depth.

Meanwhile, literature reveals another research which explore planning processes in detail and found arelationship between the quality of planning and project success (Zwikael and Globerson, 2006). They identified the following six planning processes as the ones that highly contribute to project success:

(1) definition of activities to be performed in the project;

(2) schedule development;

(3) organisational planning;

(4) staff acquisition;

(5) communications planning; and

(6) development of a project plan.

Moreover, Zwikael and Smyrk (2006) found discrepancy in the literature and found that most scholars and practitioners agree planning improves project success, others claim there is no correlation between planning and various success dimensions in regarding to research and development projects (Dvir et al. 2003).In addition, Bigelow (1998) criticizes the importance of planning by quoting project managers who claim that planning takes too much time. For clarifying this question Zwikael et al. (2005) explore cultural differences in project planning quality between Japan and Israel. We try to expand their study through investigating planning quality in Kazakhstan and compare results with Japanese and Israeli findings. For doing this we focus on cultural background at the next part of study.

\subsection{Cultural background}

Trompenaars agreed that culture was based on languages, economy, religion, policies, social institutions, class, values, status, attitudes, manners, customs, material items, aesthetics and education, which subsequently influenced managerial values (Trompenaars, 1993). Thus, it is not surprise that people who are different by such long list of positions run projects in different manner.

Culture attracted a lot of attention among world scholars, thus big amount of researchers explore influence of the culture on political, economic and social values (Shchurko et al. 2016; Mukhtarova et al., 2016), the role of social industries in an economic grow (Vitkauskaite, 2015), influence of social and cultural factors on project management (Bredillet et al. 2010). For example, Ochieng and Price (2010) investigated how cultural differences in communications can influence to project team. Eriksson et al. (2002) found that culture influences to project performance. Further, was explored that how culture affects to project planning (Zwikael, 2009) and on risk assessment (Zwikael \& Ahn, 2011; Keil et al. 2000). Rees-Caldwell and Pinnington (2012) conducted worthwhile investigating differences in how projects run by British and Arab labour. Specifically, they explored how does the Arab and the British national cultures influence project managers' perceptions of project planning. Furthermore, Zwikael (2009) investigated the common management practices in New Zealand, which focused on project management. The study presented the results of the first 
vast project management research held in New Zealand, and compared project management capabilities in New Zealand with other countries.

Zwikael et al. (2005) investigated differences in project management (further PM) style between Japanese and Israeli managers. They found that Israeli project managers more focused on performing "scope" and "time" management processes, while Japanese project managers focused on "communications" and "cost" management.

Zwikael et al. (2005) claim that the Israeli managerial culture seems to be of a similar nature to that of the western world, especially the American one. He concluded that Israeli project managers pay more attention to time planning, Japanese managers make more use of cost estimation and communication planning processes.

Japanese prefer to develop personal relationship first before going forward with any business transaction. Therefore, they pay more attention to communications when execute projects (Lee and McCalman, 2008).

Kazakhstan is newly industrialized country with emerging economy (Smagulova et al. 2018; Seidaliyeva et al. 2018; Kusmoldayeva \& Khudaibergenova, 2017) that can`t compete with leading countries (Sabden \& Turginbayeva, 2017). But it is a stable and rapidly developing nation that having passed a hard way since its 28 year independence (Mukhtarova et al. 2017; Alimova, 2017). There are lack of studies dedicated to Kazakh PM culture. The need for application of the best PM practices has increased in Kazakhstan since its independence in the 1990s and the local research in this field gained an interest in the early 2000s (Narbaev, 2015). There are lack of qualified PM specialists in Kazakhstan (Mukhtarova \& Kozhakhmetova, 2017; Jumambayev, 2018). Furthermore, public-private projects of Kazakhstan often implemented insufficiently in Kazakhstan due to the weakness of project implementation controlling system. Also, projects` time and cost scheduling are controlled by government (Dyussembekova, 2016; Dzhulaeva, 2017). This fact may prove an idea that Kazakh projects have high level of time and cost planning.

Thus, the literature review emphasizes the high impact of planning and culture on project success and luck of information about cultural differences in performing PM knowledge areas between Kazakhstan, Japan and Israel. Hence, at the next part of the study we may rise the hypothesis based on the literature review.

\section{Hypothesis development}

The literature provides us with the next distinctions in performing PM knowledge areas by chosen three countries.

Table 1. Performing PM knowledge areas by Japan, Israel and Kazakhstan

\begin{tabular}{lllll}
\hline № & Project knowledge area & Low importance & High importance & Literature source \\
\hline 1 & Integration & - & Israel & (Zwikael et al., 2005) \\
\hline 2 & Scope & - & Israel & (Zwikael et al., 2005) \\
\hline 3 & Time & - & Japan, Israel, & Kazakhstan \\
& & & $\begin{array}{l}\text { (Globerson and Zwikael, 2002; Jacobs } \\
\text { and Herbing, 1998; } \\
\text { Dyussembekova,2016) }\end{array}$ \\
\hline 4 & Cost & Japan & (Jacobs and Herbing, 1998; Zwikael et al., \\
& & - & Japan & (Dumaine,1991) \\
\hline 5 & Quality & - & Japan & (Jacobs and Herbing, 1998) \\
\hline 6 & HR & - & Japan & (Jonathan et al., 2008) \\
\hline 7 & Communications & - & - & (Zwikael et al., 2005) \\
\hline 8 & Risks & Japan, Israel & No findings & - \\
\hline 9 & Procurement & No findings & Japan & (Jonathan et al., 2008) \\
\hline 10 & Stakeholders & - & & \\
\hline
\end{tabular}

Source: own compilation. 
As depicted in Table 1, Japan is described by literature as leading in quality and communication. Especially, Japan is well-known with its high-quality management standards and control. Further Israeli project managers identified as good performers of integration, scope and time planning, but no specific finding in literature about Kazakh project managers except that they spend more efforts to time and cost (Dyussembekova, 2016).

Authors put forward the several hypotheses related to differences of three countries revealed from literature review.

Kazakhstan less experienced in PM, rare use PM tools and has problems with qualified project managers (Karmazina et al. 2014; Tsekhovoy and Statsenko, 2014). Many scientists claim that qualified manager is one of the critical factors in project success (Dyett, 2011; Blascovics, 2016). In addition, if they use PM tools less, it seems like they use planning processes less too. The planning performance affects to project success too (Zwikael and Sadeh, 2007). It means that Kazakh projects often failed than Japanese and Israeli, because managers rare use planning processes. Thus, the first hypothesis assumes that Japanese and Israeli projects are more successful than Kazakh projects.

Japanese managers have high sense of communicationand traditionally known for their quality (Lee and McCalman, 2008), therefore the second hypothesis assumes that Japanese project managers invest more effort to communication and quality knowledge areas than project managers from Israel and Kazakhstan.

Israeli managers focus on integration and scope areas (Zwikael et al. 2005), therefore, the third hypothesis assumes that they perform integration and scope planning processes better than Japan and Kazakhstan.

The most Kazakh projects supported by government, so time and cost scheduling of these projects controlled by government (Dyussembekova, 2016). This fact let us to put forward the fourth hypothesis which claims that Kazakhstani projects don't have lowest level of time and cost planning.

The literature reports that PM practises associated with time, scope and cost are more often used. Practices related to integration, human resources and procurement used somewhat less, and finally, practises related to communication, quality and risk least frequently used by project managers (Schwalbe, 2009). Based on findings the fifth hypothesis claims that cost, time and scope planning processes most performed by Japan, Israeli and Kazakh project managers, communication, quality and risk processes performed less in all three countries.

The literature reveals opposite statements regard to performing PM tools by Kazakh managers. One group of authors claim that project management in Kazakhstan is slow developed and PM tools and techniques don`t used by local managers, don`t accepted by local companies (Narbaev, 2015; Abdramanova, 2014). Others protect the idea that local managers (70\%) actively use PM methods and tools during performing a project (Dyussembekova, 2016; Tsekhovoy and Statsenko, 2014). Therefore, the sixth hypothesis assumes that there are the lowest level of the organizational support in Kazakhstan and local managers less supported by their organization than Japan and Israel.

\section{Methodological approach}

\subsection{The model}

Many years ago Dr. Globerson said "If planning isn`t properly done, project can fail. The problem is how to evaluate whether the planning is properly done or not" (Marcia, 2005). Thus, he faced with absence of specific planning assessment tools. His research team created a measurement tool for analysing planning processes which called Project Management Planning Quality (PMPQ) model after conducting a deep research (Zwikael and Globerson, 
2004). They used Project Management Planning Quality (further PMPQ) model to evaluate projects in different industries, and found that the model is a valid and reliable for measuring the impact of planning and organizational support on project success. The model was checked by several statistical tests as Cronbach`s alpha (0.91 and 0.93) and t-test (Zwikael and Globerson, 2004). Furthermore, this model used by another scholars (Ress-Caldwell and Pinnington, 2012; Papke-Shields et al. 2010).

PMPQ index highly correlates ( $r>0.7$ ) with projects' success dimensions.

This index shows average extent of use 16 planning processes in each project. Extent of use of each process is measured by Likert scale from 1 to 5 (from low to high). Finally, we calculate average extent of use of all 16 planning processes for single project. Thus, we calculate the PMPQ index.

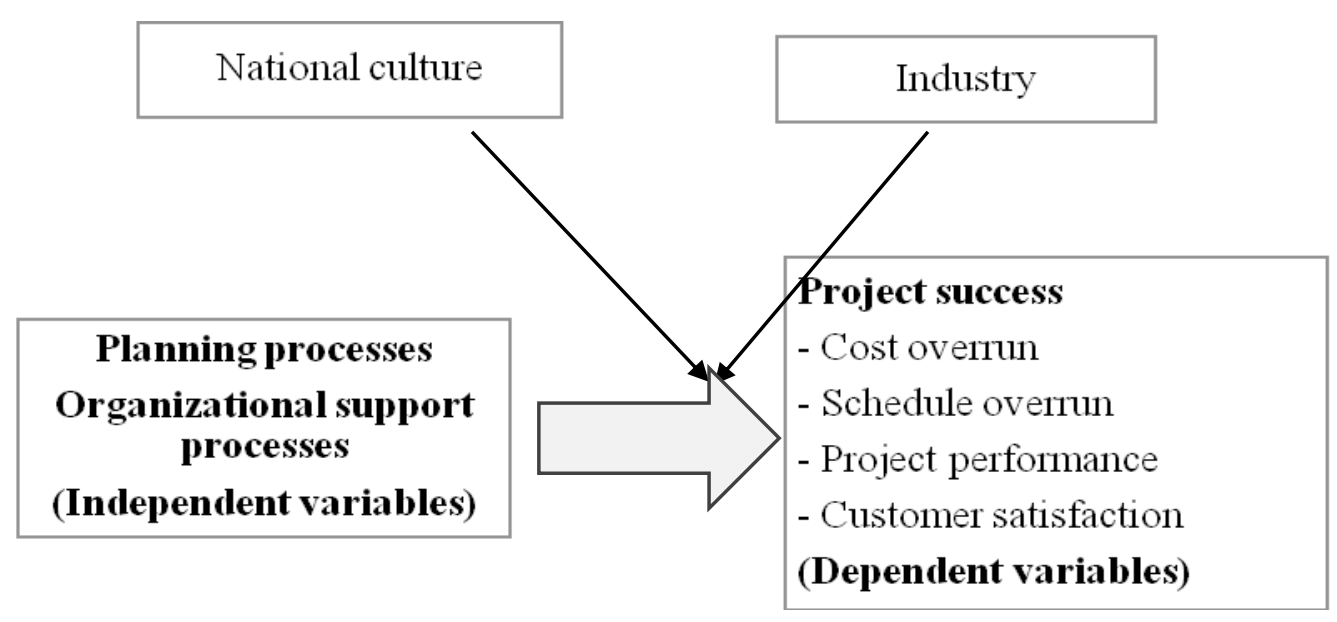

Figure 1. The research model.

Source: own data.

As depicted in Fig. 1, the model helps to identify interrelations between independent (16 planning processes and 17 organizational support processes) and dependent variables (cost overrun, schedule overrun, project performance, customer satisfaction). Planning processes had an average correlation with cost overrun and schedule overrun $(r>0.6)$ and very high correlation with customer satisfaction and project performance ( $r>0.9)$. National culture and industry act as moderators between independent and dependent variables, because they may affect to both variables.

\subsection{Data collection}

The original survey was conducted among project managers of Japan and Israel by Zwikael et al. (2005). Then it was translated to Kazakh and Russian language and was sent to supervisors and project managers from Kazakhstan. Finally, were received 681 valid questionnaires from project managers from different industries.

Participated project managers were asked about use intensity of 16 planning processes and 17 organizational support processes. Use intensity identified by rank from 1 to 5 Likert scale. Moreover, project supervisors evaluated 4 success dimensions. Cost and schedule overrun measured by percentages, technical performance and customer satisfaction measured by scale ranging from 1 to 10 . 
Questionnaires which items were fulfilled at least $85 \%$ was included in the final data analysis. Collected data about types of projects presented in Table 2.

Table 2. Types of projects by countries and industries

\begin{tabular}{lllll}
\hline$№$ & Project type & Japan, \% & Israel, \% & Kazakhstan, \% \\
\hline 1 & Engineering & 18 & 24 & 23 \\
\hline 2 & Software & 70 & 51 & 49 \\
\hline 3 & Communications & 4 & 20 & 19 \\
\hline 4 & Services & 8 & 5 & 9 \\
\hline 5 & Total & 100 & 100 & 100 \\
\hline
\end{tabular}

Source: own compilation.

As depicted in Table 2, data analysis consists the next industries: engineering, software, communications and service.

All evaluations were conducted by using SPSS Statistics program. Moreover, according to validity test for the model, results are significant. They were singled out in Table 3.

Table 3. Validity test for the data

\begin{tabular}{lllllr}
\hline № & Success measure & $\mathrm{R}$ & $p$-value & Meaning & \\
\hline 1 & Cost overrun & 0.61 & $<0.001$ & $\begin{array}{l}\text { Average } \\
\text { significance }\end{array}$ & correlation, \\
\hline 2 & Schedule overrun & 0.67 & $<0.001$ & $\begin{array}{l}\text { Average correlation, } \\
\text { significance }\end{array}$ & high \\
\hline 3 & Customer satisfaction & 0.89 & $0.001=$ & High correlation, high significance \\
\hline 4 & Project performance & 0.91 & $<0.001$ & $\begin{array}{l}\text { Very high correlation, high } \\
\text { significance }\end{array}$ \\
\hline
\end{tabular}

Source: own compilation.

As it can be seen from the Table 3, collected data are valid and reliable for using in this research. The correlation between variables are high and results are significant.

\section{Conducting research and results}

\subsection{Project success level}

The results in Fig. 2 show the project success level in chosen countries.

Fig. 2 shows that cost overrun and schedule overrun well performed by Japanese managers, but the level of technical performance and customer satisfaction are not so high like in Israel. We assume that this is features of Japanese culture - to pay significant attention to scheduling. Also, it may be result of spending more efforts on cost and time planning, because use intensity of planning processes strongly correlates with projects success dimensions. It will be clear on the next section of the analysis when we will discuss the performance of planning processes by three countries` managers. These results also help to clarify why Kazakhstani projects have the worst level of the cost overrun $(25,96 \%)$. 
RECENT ISSUES IN SOCIOLOGICAL RESEARCH

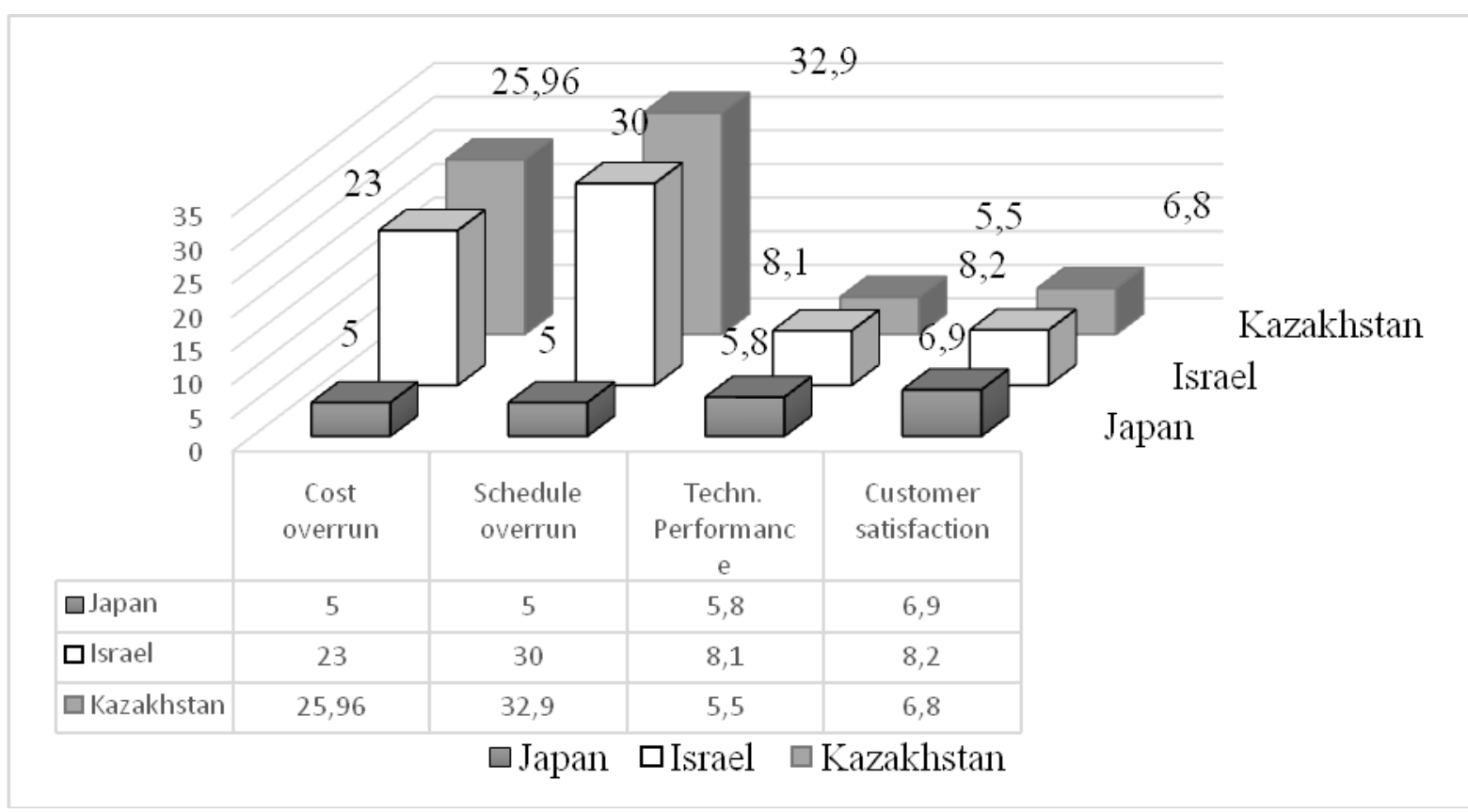

Figure 2. Project success rate in Japan, Israel and Kazakhstan

Source: own data.

Interesting findings are opposite results of technical performance and customer satisfaction between these three countries. As depicted in the Fig. 2, the highest level of technical performance and customer satisfaction revealed in Israel. Country`s managers pay more attention on better technical performance of projects through spending more money what reflects in cost overrun and focus on customers needs. This practice repeats with Kazakh managers` behaviour in achieving technical performance, because they have a bit lower results from Japan in customer satisfaction. This finding helps to prove the first hypothesis, which assumes that Kazakhstani projects complete with the worst success outcome. Moreover, it`s important to mention that Kazakhstan has the lowest level of the technical performance. This finding can interpreted as Kazakh customers require high technical performance and managers try to do this through spending-over budget and time. They could not achieve this because of several reasons as a lack of experience and qualified project managers or spending fewer efforts to performing planning processes and low level of the organizational support. To clarify this farther study focuses on project managers 'planning performance. The research results show that projects of developed countries like Japan and Israel are more succeed than projects of developing country as Kazakhstan. It may be explained by long list of factors like experience, innovative development, competitiveness level etc. But this study focuses on PM tools and practices. Therefore, we try to clarify this by farther focusing on project managers` planning performance.

\subsection{Planning performance}

This section discusses a total vision of planning performance in three country. Authors analyse the data gathered from project managers and identify the use intensity of planning processes. This information is depicted in Table 4. 
RECENT ISSUES IN SOCIOLOGICAL RESEARCH

Table 4. Use intensity of planning processes in Japan, Israel and Kazakhstan

\begin{tabular}{llllll}
\hline № & Planning processes & $\begin{array}{l}\text { PMPQ } \\
\text { index/ } \\
\text { Japan } \\
(\mathrm{n}=83)\end{array}$ & $\begin{array}{l}\text { PMPQ index/ } \\
\text { Israel (n=275) }\end{array}$ & $\begin{array}{l}\text { PMPQ index / } \\
\text { Kazakhstan } \\
\text { (n=323) }\end{array}$ & P-values \\
\hline 1 & Activity definition & 3.7 & 4.1 & 3.5 & $0.001^{* *}$ \\
\hline 2 & Staff acquisition & 3.3 & 3.6 & 3.2 & $0.015^{*}$ \\
\hline 3 & Project plan development & 3.7 & 4.0 & 3.5 & $0.021^{*}$ \\
\hline 4 & Resource planning & 3.5 & 3.7 & 3.3 & $0.022^{*}$ \\
\hline 5 & Activity duration estimating & 4.0 & 4.2 & 3.9 & $0.035^{*}$ \\
\hline 6 & Scope planning & 3.9 & 4.1 & 3.8 & 0.072 \\
\hline 7 & Procurement planning & 2.9 & 3.0 & 2.8 & 0.350 \\
\hline 8 & Organizational planning & 3.7 & 3.8 & 3.6 & 0.256 \\
\hline 9 & Risk management planning & 2.8 & 2.8 & 2.5 & 0.491 \\
\hline 10 & Quality planning & 3.0 & 2.9 & 2.8 & 0.450 \\
\hline 11 & Activity sequencing & 3.6 & 3.5 & 3.2 & 0.372 \\
\hline 12 & Schedule development & 4.1 & 4.0 & 3.8 & 0.125 \\
\hline 13 & Scope definition & 3.8 & 3.7 & 3.2 & 0.198 \\
\hline 14 & Cost budgeting & 3.4 & 3.2 & 3.0 & $0.001^{* *}$ \\
\hline 15 & Communication planning & 2.9 & 2.4 & 2.1 & $0.001^{* *}$ \\
\hline 16 & Cost estimating & 4.1 & 3.0 & 2.5 & \\
\hline
\end{tabular}

Note: ${ }^{*} \mathrm{p} \leq 0.05: * * \mathrm{p} \leq 0.001$ (High significance)

Source: own compilation.

Table 4 shows essential differences in planning performance between chosen countries. Japanese managers perform cost budgeting, cost estimating, schedule, quality and communication processes better than two other countries. This finding approves the second hypothesis that claims Japanese managers perform communication and quality planning processes better than Israeli and Kazakhstani.

As depicted in Table 4, Israeli managers have higher results in integration, scope planning and human resource management in comparison with other two countries. This finding proves the third hypothesis, which assumes that Israeli projects perform integration and scope better than Japan and Kazakhstan.

The fourth hypothesis assumes that time and cost aspects of most Kazakhstani projects regulated by government, thus time and cost management better performed by Kazakh managers. This hypothesis rejected, because Kazakhstani results in cost budgeting and cost estimating lower than Japanese results and Israeli. Extent of using time planning processes lower than Japanese and Israeli results too. As results show, project managers from Kazakhstan make little use of PM processes. Low level of PMPQ index explains the lowest level of project success in this country. It`s necessary to develop a national standard for PM and to train qualified project managers through using a foreign experience.

The fifth hypothesis claims that scope, cost and time processes more often performed by three countries` managers, and communication, risk and quality least performed by three countries`managers. The most often performed processes by three countries` managers were shown in Table 5.

Table 5 shows that the most used knowledge areas are time, cost and schedule management in all chosen countries, and least used areas are communication, risk and quality management. Thus, the fifth hypothesis can be accepted as a true. We may explain these findings through effect of "Golden triangle". Precisely, the components of "Golden triangle" like time and cost are often used and well-known by project managers all over the world. Therefore, project managers often use the common processes than necessary and difficult processes like risk management and quality management during project running. 
Table 5. Maximum and minimum extent of use planning processes by Japan, Israel and Kazakhstan

\begin{tabular}{llll}
\hline & Country & Most used planning processes & Least used planning processes \\
\hline 1 & Japan & $\begin{array}{l}\text { Cost estimating, schedule development, } \\
\text { activity duration estimating, scope } \\
\text { planning. }\end{array}$ & $\begin{array}{l}\text { Risk management planning, } \\
\text { communication planning, } \\
\text { procurementplanning, quality } \\
\text { planning. }\end{array}$ \\
\hline 2 & Israel & $\begin{array}{l}\text { Activity duration estimating, activity } \\
\text { definition, scope planning, schedule } \\
\text { development. }\end{array}$ & $\begin{array}{l}\text { Communication planning, risk } \\
\text { management planning, quality } \\
\text { planning. }\end{array}$ \\
\hline 3 & Kazakhstan & $\begin{array}{l}\text { Project plan development, activity } \\
\text { definition, scope planning, schedule } \\
\text { development. }\end{array}$ & $\begin{array}{l}\text { Communication planning, risk } \\
\text { management planning, quality } \\
\text { planning. }\end{array}$ \\
\hline
\end{tabular}

Source: own compilation

Further study focuses on analysis of organizational support level in chosen countries, which can help to clarify the impact of cultural differences on perception of organizational support to project success.

\subsection{Organizational support level}

PMPQ index of the organizational support measured by average extent of use of organizational support processes (Table 6).

As depicted in Table 6, Israeli companies support their project managers much better than Japan and Kazakhstan: leads Japan by 10 points and leads Kazakhstan by all points. Zwikael et al. (2005) explain this as Israel is exposed to an American influence.

Moreover, these findings let to accept sixth hypothesis, which claims that Kazakhstani project managers have the lowest level of organizational support. Because as Table 6 shows, Kazakhstani results lower than Japanese and Israeli by all points. Kazakhstan is a young country with emerging economy, which try to use new techniques and approaches in all spheres. It can be push companies to prefer the modern project-based organizational structure than functional and matrix as in Israel, therefore project based organization index is slightly lower than Israeli.

The use of organizational projects data warehouse in Kazakh companies slightly higher than Japanese result. The reason of this finding may be due to the fact that Kazakh companies less experienced in PM and try to learn from previous mistakes and pay more attention to saving the data about projects for using their experience in the future. Probably almost the same level of communication between the project manager and the organization during a planning phase and project office involvement in Kazakhstan and Japan may explained in the next way: lack of Kazakhstani experience motivates and pushes organizations to actively participate in managing projects, support managers. They haven`t good results in performing other support processes as involvement in risk, quality management and others due to the lack of experience, but they try to be more active in planning and communication with managers, because it is the most common and simplest processes. 
RECENT ISSUES IN SOCIOLOGICAL RESEARCH

Table 6. Organizational support level in Japan, Israel and Kazakhstan

\begin{tabular}{|c|c|c|c|c|c|}
\hline № & $\begin{array}{l}\text { Organizational } \\
\text { processes }\end{array}$ & $\begin{array}{l}\text { PMPQ } \\
\text { index } \\
\text { Japan } \\
(\mathrm{n}=83)\end{array}$ & $\begin{array}{l}\text { PMPQ index } \\
\text { Israel } \\
(\mathrm{n}=275)\end{array}$ & $\begin{array}{l}\text { PMPQ index } \\
\text { Kazakhstan } \\
(\mathrm{n}=323)\end{array}$ & P-value \\
\hline 1 & $\begin{array}{l}\text { Extent of use of standard } \\
\text { project management software }\end{array}$ & 2.5 & 4.2 & 2.4 & $0.001 * *$ \\
\hline 2 & $\begin{array}{l}\text { Communication between the } \\
\text { project manager and the } \\
\text { organization during the } \\
\text { planning phase }\end{array}$ & 2.9 & 3.9 & 2.8 & $0.001 * *$ \\
\hline 3 & $\begin{array}{l}\text { Extent of use of new project } \\
\text { tools and techniques }\end{array}$ & 2.1 & 2.8 & 2.0 & $0.001 * *$ \\
\hline 4 & $\begin{array}{l}\text { Existence of interactive inter- } \\
\text { departmental project planning } \\
\text { groups }\end{array}$ & 2.7 & 3.5 & 2.5 & $0.001 * *$ \\
\hline 5 & Project manager assignment & 3.0 & 3.6 & 2.9 & $0.001 * *$ \\
\hline 6 & Project office involvement & 2.4 & 2.7 & 2.3 & $0.015^{*}$ \\
\hline 7 & $\begin{array}{l}\text { Extent of use of organizational } \\
\text { projects data warehouse }\end{array}$ & 2.5 & 2.8 & 2.6 & $0.007 * *$ \\
\hline 8 & $\begin{array}{l}\text { Extent of supportive project } \\
\text { organizational structure }\end{array}$ & 3.0 & 3.4 & 2.9 & $0.001 * *$ \\
\hline 9 & $\begin{array}{l}\text { Extent of organizational } \\
\text { project`s quality management }\end{array}$ & 2.8 & 3.0 & 2.7 & 0.085 \\
\hline 10 & $\begin{array}{l}\text { Extent of existence of project's } \\
\text { procedures }\end{array}$ & 3.6 & 3.7 & 3.3 & 0.112 \\
\hline 11 & $\begin{array}{l}\text { Involvement of the project } \\
\text { manager during the initiation } \\
\text { stage }\end{array}$ & 3.8 & 3.9 & 3.0 & 0.228 \\
\hline 12 & $\begin{array}{l}\text { Regular project management } \\
\text { training programs }\end{array}$ & 2.8 & 2.7 & 2.4 & 0.277 \\
\hline 13 & $\begin{array}{l}\text { Extent of refreshing project } \\
\text { procedures }\end{array}$ & 3.2 & 3.0 & 2.7 & 0.128 \\
\hline 14 & $\begin{array}{l}\text { Organizational projects risk } \\
\text { management }\end{array}$ & 3.0 & 2.8 & 2.5 & 0.109 \\
\hline 15 & $\begin{array}{l}\text { Organizational } \\
\text { resource planning }\end{array}$ & 3.3 & 3.1 & 2.8 & 0.076 \\
\hline 16 & $\begin{array}{l}\text { Existence of project success } \\
\text { measurement }\end{array}$ & 3.5 & 3.3 & 3.2 & 0.040 \\
\hline 17 & Project-based organization & 4.1 & 3.6 & 3.5 & 0.001 \\
\hline
\end{tabular}

Source: own data

Another interesting finding that use of standard project management software is much differs between countries. Israeli results are very high and this fact explains the highest results of Israeli projects in success dimension as technical performance. On the other hand, surprising finding is that Kazakhstani organizations support their managers a bit less than Japanese in using standard project management software. 


\section{Conclusion}

The research question of this study asked whether national culture differences between Japan, Israel and Kazakhstan lead to different expectations related to PM styles and project success. Results shows that managers from chosen countries run similar projects with different PM styles. Study supports statement that project managers from different national cultures often lead similar project in a completely different way (Zwikael et al. 2005).

Research findings help to accept five of the six hypotheses. Results identify typically strong and weak areas of chosen countries in performing planning quality, different level of project success. Moreover, the study reveales the positive relation between planning and project success.

Although extent of use of planning processes are not much differs between three countries, but has different level in use intensity of specific processes. For example, the data analysis reveals that scope, cost and time processes more often performed than communication, risk and quality by three countries managers. The reason of this may be that scope, cost and time are items of "golden triangle" and most common used knowledge areas in PM. Therefore, project managers may often use these processes, because they are wellknown. Furthermore, results show that Israeli managers pay more attention to time planning processes, but have the worst results in schedule overrun. It may be an impact of other weak areas such communication, quality and risk planning. Japan exceed other two countries project managers by extent of using communication and quality planning processes. These two planning processes often used by Japanese project managers than Israeli and Kazakhstani, due to the fact that Japanese national culture well-known by its quality management and high focus on teamwork which supposed to good communication skills.

Kazakhstan shows the worst results in project success level and in using PM practices. Moreover, the study concludes that one of the reasons of fail is low level of support from organization. Therefore, Kazakh managers should intensively use PM tools and practices through investigation of foreign experience. It helps to improve their PM skills. Such improvement may be possible through attracting certified PM professionals and training.

Limitations of this study are that research focuses only on planning quality and doesn $t$ cover the national cultural differences in all phases of project management, but findings may elaborated to future research related to entire project life cycle. The research considers the data from limited number of countries and industries. The next studies should investigate planning quality in the other countries, precisely in emerging countries as Kazakhstan, because the literature reveals lack of studies about PM in such countries. Moreover, there are big choice of other unexplored industries which may be considered in the future studies.

\section{Acknowledgement}

The authors wish to thank professor of Australian National University Ofer Zwikael for support and letting to use his model in this research

\section{References}

Abdramanova, G. (2014). Scientific project management and improvement of scientist`s qualifications. Zarzadzanie Publiczne, 22, 379-393.

Alimova, N. (2017). Sustainable development in Kazakhstan: patterns, problems and future perspectives. The Journal of Economic research and Business Administration, 4(122), 4-10. 
Bilovodska, O., Golysheva, I., Gryshchenko, O., \& Strunz, H. (2017). Theoretical and practical fundamentals of scientific and educational projects: a case of Ukraine. Journal of International Studies, 10(2), 119-128.

Bigelow, D. (1998). Planning is important - Why don`t we do more of it? PM network, 21, 15-26.

Blaskovics, B. (2016). The impact of project manager on project success - the case of ICT sector. Society and Economy, 38(2), 261-281.

Bredillet, C., Yatim, F., Ruiz, P. (2010). Project management deployment: The role of cultural factors. International Journal of Project Management, 28, 183-193.

Chevrier, S. (2003). Cross-cultural management in multinational project groups. Journal of World Business, 38, 141-149.

Dafoulas, G., \& Macaulay, L. (2001). Investigating cultural differences in virtual software teams. The Electronic Journal on Information Systems in Developing Countries, 7(4), 114.

Dzhulaeva, A. (2017). "Segment" approach to the development of women`s entrepreneurship and business in Kazakhstan. The Journal of Economic research and Business Administration, 4(122), 93-100.

Dyussembekova, G. (2016). Controlling the implementation of the public-private partnership (PPP) projects in the system of local strategic management. Journal of Internet Banking and Commerce, 2, 321-333.

Dumaine, B. (1991). Closing the innovation gap. Fortune, 91, 56-60.

Dvir, D., Lipovetsky, S., Shenhar, A.J., \& Tishler, A. (2003). What is really important for project success? A refined, multivariate, comprehensive analysis. International Journal of Management and Decision Making, 4(4), 382.

Dvir, D., Raz, T., \& Shenhar, A. J. (2002). An empirical analysis of the relationship between project planning and project success. International Journal of Project Management, 21(2), 89-95.

Dyett, V. (2011). Roles and Characteristics of the Project Manager in Achieving Success across the Project Life Cycle. Dissertation work. Available on https://www.sapnaonline.com

Eriksson, M., Lillieskold, J., Johnson, N., \& Novosel, D. (2002). How to manage complex multinational R\&D projects successfully. Engineering Management, 14(2), 53-60.

Yerznkyan B., Gassner L., \& Kara A. (2017). Culture, institutions, and Economic Performance. Montenegrin Journal of Economics, 13(2), 71-80.

Garbarino, S. M. (1967). Decision-making process and the study of culture change. Ethnology, 6(4), 465-470.

Glenn, G. (2008). Enterprise Resource Planning 100 Success Secrets - 100 Most Asked Questions: The Missing ERP Software, Systems, Solutions, Applications and Implementations Guide. Emereo Pty Ltd., Queensland.

Grisham, T., \& Walker, D. (2008). Cross-cultural leadership. International Journal of Managing Projects in Business, 1(3), 439-445.

Han, J. Y., Lee, H., \& Hovav, A. (2016). The effect of individual's cultural values and social capital on knowledge sharing in web-based communication environment. The journal of modern Project Management, 4(2), 189-199.

Jacobs, L., Herbing, P. (1998). Japanese product development strategies. The Journal of business \& Industrial Marketing, 13(2), 132-154.

Jetu, F. T., \& Riedl, R. (2013). Cultural values influencing project team success: An empirical investigation in Ethiopia. International Journal of Managing Projects in Business, 6(3), 425-456. 
Jumambayev, S. (2018). Forecast of labor supply in the context of labor market modernization in Kazakhstan. The Journal of Economic research and Business Administration, 4(126), 273-285.

Karmazina, L., Nekrasova, A., \& Bolatzhanuly, T. (2014). Project Management Technology development in the Republic of Kazakhstan: current situation and problems. Actual Problems of Economics, 162(12), 180-189.

Keil, M., Tan, B.C.Y., Wei, K., Saarinen, T., Tuunainen, V., \& Wassenaar, A. (2000). A cross-cultural study on escalation of commitment behaviour in software projects. MIS Quarterly, 24(2), 299-325.

Kun, Sh. M. (2009). Entrepreneurial cognition decision making research on culture. DAI-C 75/02, Dissertation Abstracts International. Retrieved from https://search.proquest.com/docview/1868022555?accountid=8330.

Kusmoldayeva, Zh., \& Khudaibergenova, S. (2017). Development of innovation in Kazakhstan: the main elements and direction. The Journal of Economic research and Business Administration, 3(121), 36-41.

Lee, J. C., \& McCalman, D. (2008). Japanese management approaches: The Fit for Project Management. International Journal of Management, 25(3), 584-594.

Marrewijk, A. (2010). Situational construction of Dutch-Indian cultural differences in global IT projects. Scandinavian Journal of Management, 26, 368-380.

Marcia, J. (2005). Plan what you preach. PM Network, 19, 8, ProQuest Central, 52.

Milosevic, D. (2002). Selecting a culturally responsive PM strategy. Technovation, 22, 493508.

Mukhtarova, K., Kupeshova, S., Ziyadin, S., \& Doszhan, R. (2017). Problems of developing the foundations of sustainable competitiveness of industrial and innovative economy in Kazakhstan. Economic Annals-XXI, 168(11-12), 38-43.

Mukhtarova, K., \& Kozhakhmetova, A. (2017). Statistical methods as a tool of high-tech products quality management. Bulletin of the National Academy of Sciences the Republic of Kazakhstan, 3, 243-250.

Mukhtarova K., Trifilova A., \& Zhidebekkyzy A. (2016). Commercialization of green technologies: An exploratory literature review. Journal of International Studies, 9(3), 75-87.

Muller, R., Spang, K., \& Ozcan, S. (2013). Cultural differences in decision making in project teams. International Journal of Managing Projects in Business, 2(1), 70-93.

Muriithi, N., \& Crawford, L. (2003). Approaches To Project Management In Africa: Implications For International Developments. International Journal of Project Management, 21, 309-319.

Narbaev, T. (2015). Project Management Knowledge Discovery in Kazakhstan: Co-Word Analysis of the Field. International Conference on Intellectual Capital and Knowledge Management and Organisational Learning; Kidmore End: 169-176.

Ngai, E., Law, C., \& Wat, F. (2008). Examining the critical success factors in the adoption of enterprise resource planning. Computers in Industry, 59(6), 548-564.

Ochieng, E., \& Price, A. (2010). Managing cross-cultural communication in multicultural construction project teams: The case of Kenya and UK. International Journal of Project Management, 28, 449-460.

Ochieng, E., \& Price, A. (2009). Framework for managing multicultural project teams. Engineering, Construction and Architectural Management, 16(6), 527-543.

Orr, R. J., Scott, W. R. (2008). Institutional exceptions on global projects: A process model. Journal of International Business Studies, 39(4), 562-588. 
Papke-Shields, K., Beise, C., \& Quan, J. (2010). Do project managers practice what they preach, and does it matter for project success? International journal of project management, 28, 650-662.

Pinto, J. K., \& Slevin, D. P. (1988). Critical success factors across the project life cycle. Project Management Journal, 19, 67-75.

PMI Standards Committee. (2008). A Guide to the Project Management Body of Knowledge: 4th Edition. Newtown Square.

Raisiene, A.G., Pulokiene, A., \& Valickas, A. (2018). Examining Leadership Characteristics at International Multilaterals. Montenegrin Journal of Economics, 14(3), 189-198.

Remenova, K., Skorkova, Z., \& Jankelova, N. (2018). Span of Control in Teamwork and Organization Structure. Montenegrin Journal of Economics, 14(2), 155-165.

Ress-Caldwell, K., \& Pinnington, A.H. (2012). National culture differences in project management: Comparing British and Arab project managers` perceptions of different planning areas. International Journal of Project Management, 31, 212-227.

Sabden, O., Turginbayeva, A. (2017). Transformation of National Model of Small Innovation Business Development. Academy of Entrepreneurship Journal, 23(2), 95-109.

Seidaliyeva, D., Kirdasinova, A., Tazhikenova, S., Utarbayeva, G., Uskelenova, A., \& Akhmetova, Z. (2018). Innovation Management in the Kazakhstan Industrial Sector. Int. J. Manag. Bus. Res., 8(1), 199-209.

Serrador, P. (2013). The impact of planning on project succsess - A literature review. The Journal of Modern Project Management, 1(2), 221-234.

Shane, S. (1994). Championing change in the global corporation. Research-Technology Management, 37(5), 29-35.

Shchurko, U., Datsko, O., \& Dudáš, T. (2016). Socioeconomic and Cultural Dimensions of National Identity in the Globalized World. Journal of International Studies, 9(3), 255269.

Schwalbe, K. (2009). An Introduction to Project Management, second ed. Course Technology Cengage Learning, Boston, MA.

Smagulova, Sh., Nurseiytova, G., Madjarova, R., Spankulova, L., Koptayeva, G., Dzhunusov, A., Omarkulova, M., Bikenova, A., Turekulova, A., \& Imashev, A. (2018). Entrepreneurship and Investment Environment in the Central Asian Transition Countries: Case Kazakhstan. Academy of Entrepreneurship Journal, 4(24), 22-31.

Staples, D. S., \& Zhao, L. (2006). The effects of cultural diversity in virtual teams versus face-to-face teams. Group Decision and Negotiation, 15(4), 389-406.

Trompenaars, F. (1993). Riding the waves of culture. Understanding cultural diversity in business. London: The Economist Books Ltd.

Tsekhovoy, A., \& Statsenko, L. (2014). Transition to the standards of management of subsoil use projects is an urgent task. Gornyi Zhurnal, (5), 79-80.

Vitkauskaite, I. (2015). Cultural industries in public policy. Journal of International Studies, $8(1), 208-222$.

Yasin, M. M., Zimmer, T. W., \& Wafa, M. A. (1997). American vs Arab project managers: the road to effectiveness. Cross Cultural Management, 4(4), 17-28.

Zwikael, O., Shimizu, K., \& Globerson, Sh. (2005). Cultural differences in project management capabilities: A field study. International Journal of Project Management, $23,454-462$.

Zwikael, O., \& Sadeh, A. (2007). Planning effort as an effective risk management tool. Journal of Operations Management, 25(6), 454-62.

Zwikael, O. (2009). Critical planning processes in construction projects. Construction innovation, 9(4), 372-387. 
Zwikael, O., \& Ahn, M. (2011). The effectiveness of risk management. Risk Analysis, 31(1), 25-37.

Zwikael, O. (2009). The uniqueness of management in New Zealand - the project management case. Problems and Perspectives in Management, 7(1), 15-20.

Zwikael, O., \& Smyrk, J. (2011). Project Management for the Creation of Organizational Value. Springer-Verlag London.

Zwikael, O., \& Globerson, Sh. (2006). Benchmarking of project planning and success in selected industries. Benchmarking: An International Journal, 13 (6), 688-700.

Zwikael, O., \& Globerson, Sh. (2004). Evaluating the quality of project planning: a model and field results. Int. J. Prod. Res, 42(8), 1545-1556.

"2015 Investment Climate Statement - Kazakhstan". US State Department, 1 May 2017. Retrieved from https://www.state.gov/documents/organization/241825.pdf. 